\title{
IMPLEMENTASI KEBIJAKAN PENGEMBANGAN KOMPETENSI SUMBER DAYA APARATUR SIPIL NEGARA DI KABUPATEN YALIMO PROVINSI PAPUA
}

\author{
Leonard Nekwek \\ Program Pascasarjana Institut Pemerintahan Dalam Negeri, Jakarta \\ email: leonardipdn32@gmail.com
}

Paper Accepted: 25 Desember 2021
Paper Reviewed: 01-06 Januari 2022
Paper Edited: 08-15 Januari 2022
Paper Approved: 18 Januari 2022

\begin{abstract}
ABSTRAK
Pegawai Negeri Sipil (PNS) merupakan unsur utama sumber daya manusia yang mempunyai peranan penting dalam menentukan keberhasilan penyelenggaraan pemerintahan dan pembangunan. Penelitian ini bertujuan untuk mengetahui bagaimana implementasi kebijakan pengembangan kompetensi sumber daya ASN di Kabupaten Yalimo, faktor-faktor penghambat, serta upaya-upaya yang dilakukan BKPSDM Kabupaten Yalimo agar perannya dapat berjalan dengan baik. Metode penelitian yang digunakan adalah metode kualitatif dengan strategi penelitian studi kasus dan pendekatan teori secara deduktif. Informan ditentukan dengan teknik purposive sampling. Informan terdiri dari dalam BKPSDM dan SKPD lainnya. Hasil penelitian menunjukan bahwa implementasi kebijakan masih belum berjalan dengan optimal. Berdasarkan teori George C Edwards III, dari empat dimensi penentu keberhasilan sebuah implementasi kebijakan yaitu komunikasi, sumber daya, disposisi/sikap pelaksana dan struktur birokrasi, terdapat faktor penghambat yaitu faktor keterbatasan anggaran, faktor keterbatasan fasilitas dan faktor politik. Berbagai upaya telah dilakukan BPKSDM Kabupaten Yalimo di antaranya melakukan perbaikan proses perencaanan anggaran dan fasilitas, membangun komunikasi dan koordinasi yang intensif ke pihak penyelenggara, menyampaikan telaahan staf dan menyusun standar operasional prosedur agar ada transparansi dalam penetapan peserta Diklat PIM. Implementasi kebijakan pengembangan kompetensi sumber daya ASN di Kabupaten Yalimo belum berjalan dengan optimal sehingga diperlukan penataan komunikasi, sumber daya, disposisi, pola kerja/struktur birokrasi, dan perbaikan perencanaan anggaran dengan data yang akurat. Selain itu, diperlukan adanya penambahan anggaran, fasilitas dan penataan proses seleksi peserta Diklat PIM secara transparan serta pengangkatan pejabat struktural sesuai dengan kompetensi ASN.
\end{abstract}

Kata kunci : Implementasi Kebijakan, pengembangan kompetensi SDM ASN, Diklat Kepemimpinan

\section{PENDAHULUAN}

Latar Belakang

Pegawai Negeri Sipil (PNS) merupakan unsur utama sumber daya manusia, yang mempunyai peranan penting dalam menentukan keberhasilan penyelenggaraan pemerintahan dan pembangunan. Berdasarkan Peraturan Kepala Lembaga Administrasi Negara Nomor 18, 19, dan 20 Tahun 2015 
Tentang Pedoman Penyelenggaraan Pendidikan dan Pelatihan Kepemimpinan Tingkat II, III dan IV menerangkan bahwa Pendidikan Pelatihan Kepemimpinan (DIKLAT PIM) diselenggarakan untuk membekali peserta dengan kompetensi yang dibutuhkan menjadi pemimpin yang mampu menerapkan kompetensi yang dimilikinya. Implementasi kebijakan pengembangan kompetensi aparatur ASN tersebut, diharapkan dapat mewujudkan atau menciptakan ASN yang memiliki kompetensi tinggi dalam menjalankan tugas dan jabatan secara profesional. Untuk itu, sangat wajar apabila pemerintah daerah memberikan perhatian yang memadai terhadap pengembangan kompetensi Aparatur Sipil Negara (ASN/PNS) daerah .

Untuk meningkatkan sumber daya manusia tersebut, Pemerintah Daerah Kabupaten Yalimo telah menetapkan Peraturan Daerah Nomor 5 Tahun 2014 tentang Perangkat Daerah dan ditetapkan Peraturan Bupati Yalimo Nomor 16 Tahun 2016 tentang Kedudukan, Susunan Organisasi, Tugas dan Fungsi, serta tata Kerja Badan Kepegawaian dan Pengembangan Sumber Daya Manusia Kabupaten Yalimo.

Berdasarkan data kepegawaian di Kabupaten Yalimo saat ini, nampaknya kompetensi aparatur masih merupakan persoalan yang perlu mendapat perhatian terutama dilihat dari segi kompetensi pengetahuan/intelektual (pendidikan formal), kompetensi keterampilan melalui pelatihan struktural, pelatihan teknis/fungsional, penataran dan kursus, dan kompetensi pengalaman masa kerja, pengalaman jabatan/kepemimpinan, serta kompetensi sikap.

Dari data yang diperoleh menunjukkan sebagian besar pejabat Struktural baik itu Eselon II, Eselon III dan IV lebih dominan berlatar belakang seorang pendidik (Guru) dan Perawat (Mantri dan suster). Sebagian besar aparatur/pegawai belum pernah memperoleh pendidikan dan pelatihan (Diklat) Struktural, akibatnya ada jabatan struktural di Kabupaten Yalimo dijabat oleh pegawai yang belum memenuhi persyaratan kompetensi manajerial yang ditetapkan untuk jabatan tersebut.

Kenyataan lain menunjukkan bahwa sebagian pegawai yang menduduki jabatan struktural Eselon III dan dan Eselon IV masih kurang dalam kompetensi pengalaman karena rata-rata punya masa kerja kurang dari delapan tahun. Penelitian tentang implementasi kebijakan pengembangan kompetensi sumber daya ASN di Kabupaten Yalimo berdasarkan Peraturan Bupati Yalimo Nomor 16 Tahun 2016 tentang Kedudukan, Susunan Organisasi, Tugas dan Fungsi, serta tata Kerja Badan Kepegawaian dan Pengembangan Sumber Daya Manusia Kabupaten Yalimo perlu kirannya dilakukan untuk mengkaji sejauh mana kebijakan tersebut mampu menjadi solusi atas perkembangan kebutuhan daerah terhadap pengembangan kompetensi ASN seperti yang diharapkan.

\section{Perumusan Masalah}

Berdasarkan latar belakang dan identifikasi masalah tersebut, maka rumusan masalah yang diangkat dalam penelitian ini adalah: bagaimana implementasi kebijakan pengembangan kompetensi sumber daya Aparatur Sipil Negara di Kabupaten Yalimo Provinsi Papua. Peneliti membatasi permasalahan pada Implementasi Kebijakan Pengembangan Kompetensi Sumber Daya Aparatur Sipil Negara di Kabupaten Yalimo melalui Pendidikan dan Latihan Struktural/penjenjangan/Kepeimpinan (Diklat PIM) ASN.

\section{METODE PENELITIAN}

Penelitian ini menggunakan metode kualitatif dengan strategi penelitian studi kasus dan pendekatan teori secara deduktif. Selanjutnya penulis mengelaborasi desain metode penelitian tersebut dengan menyertakan teori pendukung mengapa peneliti menggunakan desain ini dan mensinkronisasikannya dengan tujuan penelitian. Studi kasus digunakan dalam penelitian ini oleh karena sifat dari desainnya itu sendiri, di mana sebuah kasus dapat berupa individu, grup organisasi, komunitas, contoh, episode, peristiwa, 
subkelompok populasi, atau kota (Kumar, 2011, p.126).

Berdasarkan kategori sumber data, penelitian ini pada dasarnya akan mempergunakan data primer dan sekunder secara bersamaan. Data primer diperoleh dari individu maupun organisasi melalui observasi, diskusi group dan interview. Jumlah informan tidak dapat diambil dengan jumlah sedikit ataupun banyak, tergantung dari tepat tidaknya pemilihan informan kunci (key informan) dan kompleksitas serta fenomena sosial yang diteliti sampai berakhirnya pengumpulan informasi. Dalam penelitian ini, data primer dapat berupa catatan hasil wawancara dan observasi atau pengamatan langsung dengan Bupati Yalimo sebagai informan kunci dan wawancara dengan Kepala OPD, Kepala Bidang, Kepala Seksi/Kepala sub bagian dan ASN yang telah mengikuti Pendidikan dan Pelatihan kepemimpinan (Diklat PIM) di lingkungan pemerintah Kabupaten Yalimo. Data sekunder dalam penelitian ini bersumber dari data, buku-buku refrensi, UndangUndang Nomor 5 Tahun 2014 tentang Aparatur Sipil Negara, Peraturan Pemerintah Nomor 17 Tahun 2016 tentang Manajemen Aparatur Sipil Negara, Peraturan Pemerintah Nomor 18 Tahun 2016 tentang Perangkat Daerah, Peraturan Daerah Nomor 5 Tahun 2014 tentang Organisasi Perangkat Daerah, dan Peraturan Bupati Yalimo Nomor 16 Tahun 2016 tentang Kedudukan, Susunan Organisasi, Tugas dan Fungsi, serta Tata Kerja Badan Kepegawaian dan Pengembangan Sumber Daya Manusia, Laporan-laporan dari BKPSDM terkait pengembangan Kompetensi ASN melalui Diklat PIM, penelitian akademik terdahulu, jurnal, surat dan dokumen lainnya termasuk audio video dan visual. Analisis data dilakukan melalui tiga langkah yang terdiri dari reduksi data, penyajian data, penarikan kesimpulan/verifikasi data (Matthew B. Miles, 2014, p. 31-33).

\section{HASIL DAN PEMBAHASAN}

Pegawai Negeri Sipil (PNS) merupakan unsur utama sumber daya manusia yang mempunyai peranan penting dalam menentukan keberhasilan penyelenggaraan pemerintahan dan pembangunan. Sosok Aparatur yang dibutuhkan untuk menjalankan peran tersebut adalah aparatur yang memiliki iman, bertakwa, berbudi luhur, adil, professional dan sadar akan tanggungjawabnya. Sejalan dengan itu maka pemerintah Kabupaten Yalimo memberikan investasi dalam bentuk pendidikan dan pelatihan, salah satunya yaitu Pengembangan Kompetensi melalui Pendidikan dan Pelatihan Kepemimpin (Diklat PIM). Dalam hal ini, implementasi kebijakan pengembangan kompetensi sumber daya ASN di Kabupaten Yalimo dilakukan melalui Pendidikan dan Pelatihan Kepemimpinan (Diklat PIM II, III dan IV di Badan Kepegawaian Pengembangan Sumber Daya Manusia (BKPSDM) Kabupaten Yalimo.

Diklat PIM ini dikhususkan bagi Aparatur yang menduduki atau memiliki jabatan Struktural eselon II, III dan IV yang bertujuan untuk membekali peserta dengan kompetensi yang dibutuhkan menjadi pemimpin yang mampu menerapkan kompetensi yang dimilikinya seperti yang tertuang dalam Peraturan Kepala Lembaga Administrasi Negara Republik Indonesia Nomor 18, 19 dan 20 Tahun 2015.

Berdasarkan teori Edwards III yang dijadikan sebagai panduan analisis, yang merumuskan sebuah kerangka kerja hubungan antara berbagai aspek yang mempengaruhi hasil atau kinerja suatu kebijakan, implementasi kebijakan akan didukung dengan 4 (empat) aspek seperti yang dikatakan Edwards III dalam Agustino (2008:150) yaitu:

1) Komunikasi

2) Sumber Daya

3) Sikap Pelaksana/Disposisi

4) Struktur Birokrasi

\section{Faktor Komunikasi di BKPSDM Kabupaten Yalimo}

Dimensi komunikasi dalam implementasi kebijakan Pengembangan kompetensi melalui Diklat amat ditentukan dari beberapa unsur yang terdapat dalam komunikasi, seperti penyampaian pesan, isi pesan, media yang digunakan, serta sasaran penerima pesan, serta perubahan sebagai 
akibat komunikasi. Mengenai bagaimana dimensi komunikasi yang terjadi di Kabupaten Yalimo dapat dideskripsikan sebagai berikut :

\section{Transmisi/Saluran Komunikasi di BKPSDM}

Untuk mengetahui bagaimana saluran komunikasi dalam implementasi kebijakan pengembangan kompetensi sumber daya ASN di Kabupaten Yalimo, maka peneliti telah mendapatkan beberapa jawaban dari beberapa informan terkait, yang sebagian besar memberikan jawaban hampir sama, sebagaimana disampaikan oleh Bapak Lodevikus Heatubun selaku Kepala BKPSDM Kabupaten Yalimo. Beliau mengatakan bahwa secara umum, saluran komunikasi pada BKPSDM Kabupaten Yalimo cukup baik karena memang sudah jelas alurnya secara birokrasi (wawancara, senin 29 Maret 2021 pukul 10.16).

Sedangkan hasil wawancara dengan Bapak Yonathan Peyon selaku Kepala Bidang Pengembangan Sumber Daya Manusia BKSDM Kabupaten Yalimo pada hari senin, tanggal 5 April 2021 pukul 11.25 WIT mengenai saluran komunikasi atau transmisi, beliau mengatakan bahwa selama ini tidak ada masalah dalam saluran komunikasi di BKPSDM mulai dari pembuat kebijakannya (kepala daerah) sampai dengan jajarannya, karena alurnya jelas.

Berdasarkan hasil wawancara tersebut dapat disimpulkan bahwa secara umum transmisi/saluran komunikasi dalam organisasi BKPSDM tidak ada masalah, dalam artian sudah berjalan dengan baik, karena memang sudah jelas alurnya secara birokrasi dibmana kebijakan yang dibuat dari atas akan diteruskan ke struktur di bawahnya. Saluran komunikasinya pun bisa berupa perintah langsung, melalui surat tertulis, dan sarana komunikasi yang ada serta rapat-rapat.

\section{Kejelasan Perintah di BKPSDM}

Pada dasarnya hampir semua perintah yang ada di BKPSDM Kabupaten Yalimo dari struktur yang atas pasti bersifat umum dan tidak spesifik sebagaimana yang dikatakan oleh Sekretaris BKPSDM pada hari Selasa 30 Maret 2021 pukul 12.40, bahwa setiap perintah dari atasan/pimpinan umumnya berupa perintah secara umum di mana perintah yang diberikan belum jelas secara spesifik apa yang harus dikerjakan.

Hasil wawancara peneliti dengan Kabid Pengembangan SDM ASN pada hari Selasa tanggal 30 Maret 2021 pukul 14.20 WIT mengatakan bahwa kalau berdasarkan rantai komando, perintah sangat jelas, hanya saja perintah dari atasan itu memang sifatnya umum. Namun karena memang sudah menjadi pekerjaan rutin, maka perintah tersebut sudah dipahami untuk dikerjakan.

Berdasarkan jawaban dari informan tersebut dapat dikatakan bahwa hampir setiap perintah dari struktur atas tidak pernah secara spesifik. Hanya saja karena perintah tersebut berhubungan dengan pekerjaan yang rutin, maka staf bisa memahami perintah tersebut, kecuali dalam pelaksanaan sebuah peraturan yang baru walaupun jelas juklak dan juknisnya tetap saja akan dilakukan rapat-rapat pembahasan di tingkat pejabat struktural, sehingga terdapat pemahaman yang sama serta lebih jelas apa yang diinginkan dari sebuah kebijakan termasuk pengembangan kompetensi sumber daya ASN itu sendiri.

\section{Konsistensi Perintah di BKPSDM}

Perintah implementasi harus konsisten dan jelas jika ingin pelaksanaan kebijakan menjadi efektif. Konsistensi perintah terkadang terhalang oleh kepentingan dari penentu kebijakan seperti yang disampaikan oleh Bapak Yonatan Peyon selaku Kabid Pengembangan SDM pada Senin tanggal 5 April 2021 pukul 11.30 WIT. Beliau mengatakan bahwa perintah terkadang tidak konsisten, sering berubah-ubah, seperti misalnya BKPSDM sudah menyiapkan data peserta yang mengikuti Diklat PIM yang telah memenuhi syarat, namun penentu kebijakan tidak konsisten dalam peran dan fungsi BKPSDM.

Pernyataan-pernyataan tersebut mengindikasikan bahwa konsistensi perintah terkadang dapat berubah karena ada kepentingan dari penentu kebijakan, atau kepentingan pimpinan pemerintahan. Hal ini terlihat dari proses pengiriman 
peserta diklat kepemimpinan baik itu Diklat PIM II, III maupun Diklat PIM IV, yang berjalan mulai dari seleksi sampai dengan penetapan nama-nama peserta diklat kepemimpinan, di mana proses usulan nama-nama calon perta diklat tersebut merupakan yang diusulkan oleh Kepala Organisasi Perangkat Daerah (OPD), maka usulan dari perangkat daerah tersebut tidak dapat tertampung.

Menurut Edward III dalam Subarsono (2009, p:90), keberhasilan implementasi kebijakan mensyaratkan agar implementor mengetahui apa yang harus dilakukan, apa yang menjadi tujuan dan sasaran kebijakan harus ditransmisikan kepada kelompok (target group) sehingga akan mengurangi distorsi implementasi.

\section{Faktor Sumber Daya di BKPSDM}

Perintah implementasi dapat secara tepat disalurkan, jelas, dan konsisten, tetapi apabila pelaksana kekurangan sumberdaya yang penting untuk melaksanakan kebijakan, implementasi menjadi tidak efektif (George C Edwards III: 1980). Ada beberapa variabel yang termasuk sumber daya, yaitu: Staff, informasi mengenai cara kerja, berjalannya kewenangan, dan fasilitas yang memadai. Berikut pembahasan sumber daya di BKPSDM Kabupaten Yalimo.

\section{Staf di BKPSDM}

Hasil wawancara peneliti dengan Kepala BKPSDM Kabupaten Yalimo pada hari Senin 29 Maret 2021 pukul 10.20 WIT diperoleh keterangan bahwa sumber daya dari segi jumlah memang belum memadai dan staf yang mempunyai kemampuan secara teknis masih sangat kurang. Selain itu, staff yang mempunyai semangat kerja juga sangat kurang.

Pendapat yang sama juga disampaikan oleh Bapak Iselekma Wandik selaku Sekretaris BKPSDM, pada hari Selasa tanggal 30 Maret 2021 pukul 14.20 WIT. Secara umum SDM/staff yang ada masih kurang apalagi dalam hal teknis, begitu juga dalam hal kepatuhan, masih banyak staf yang kurang patuh dan bertanggung jawab. Kalau di persentasekan, staf yang kurang memiliki integritas kerja sekitar 30\% sampai $40 \%$. Selain itu, jabatan fungsional di BKPSDM belum ada.

Hasil wawancara bermakna bahwa sumber daya manusia/staf yang bekerja pada BKPSDM masih sangat kurang di mana jumlah staf BKPSDM ada 12 orang PNS, akan tetapi yang mempunyai kemampuan dan kemauan kerja hanya sedikit saja. Seperti hasil observasi di lapangan, dari sejumlah 28 Orang ASN yang ada baik yang pejabat struktural maupun staf, hanya sekitar sepuluh orang saja yang masuk kantor dan bekerja, itu pun lebih banyak yang staf, sehingga pekerjaan selalu dikerjakan oleh staf yang sama, sehingga staf sendiri merasa berat mengerjakan semua beban pekerjaan tersebut karena semua pekerjaan diberikan kepadanya.

Selain itu orang-orang atau staf yang diberikan tugas menduduki jabatan fungsional sebagai analis kepegawaian sama sekali bukan orang-orang yang ahli di bidangnya tetapi merupakan mantan pejabat yang tidak mendapatkan jabatan atau sering di sebut non job. Hal ini menyebabkan fungsi jabatan fungsional itu sendiri tidak bisa berjalan sebagaimana mestinya.

\section{Informasi Mengenai Cara Kerja}

Dalam organisasi pemerintahan, biasanya informasi mengenai cara kerja dan pekerjaan cukup jelas, karena selalu ada peraturan yang mengatur setiap pekerjaan. Dari hasil wawancara dengan Kabid Pengembangan SDM BKPSDM Kabupaten Yalimo pada hari selasa tanggal 13 April pukul 14.30 WIT, diperoleh keterangan bahwa informasi dalam pekerjaan sebenarnya sudah ada aturanaturannya dan tupoksinya sendiri, seperti Undang-undang, Peraturan Pernerintah, Perda, dan Juklak dan Juknis dalam sebuah program yang digelontorkan dari pusat. Artinya, dalam hal informasi pekerjaan sudah cukup jelas.

\section{Kewenangan di BKPSDM}

Hasil wawancara peneliti dengan Ibu Basna selaku Kasubbid Diklat Penjenjangan Struktural dan Teknis Fungsional yang juga sebagai ASN yang telah mengikuti Diklat PIM III, pada kamis tanggal 9 April 2021 pukul 12.30 WIT 
mengatakan bahwa kewenangan dari masing-masing bidang di Internal BKPSDM sendiri sudah cukup jelas tupoksinya. Jadi tidak ada yang bermasalah, hanya saja masalah diklat teknis fungsional selama ini masing-masing Organisasi Perangkat Daerah yang melaksankannya. Diklat fungsional teknis tidak terpusat di BKPSDM. Kewenangan melakukan Diklat PIM II, III dan IV ada di BKPSDM, sedangkan untuk diklat teknis dan fungsional lainnya dianggarkan di masingmasing SKPD.

\section{Fasilitas di BKPSDM}

Hasil wawancara peneliti dengan Bapak Yohanes Lani selaku Kasubbag Penyusunan Program, hari Rabu 7 April pukul 10.05 WIT yang juga ASN yang telah dilatih Diklat PIM IV mengatakan bahwa fasilitas yang ada masih kurang, seperti gedung diklat, kendaraan, meja, kursi sehingga selama ini Diklat PIM, diklat prajabatan dilaksanakan di Kabupaten Jayawijaya dan Provinsi.

Sementara hasil wawancara peneliti dengan Bapak Rinto Patandianan selaku Kasubbag Penyusunan Program Dinas Penanaman Modal dan Pelayanan Terpadu Satu Pintu Kabupaten Yalimo, hari Rabu 7 April pukul 14.20 WIT diperoleh keetrangan bahwa fasilitas Diklat PIM di BKPSDM belum memadai. Oleh karena itu peserta dikirim ke Lembaga penyelenggara baik itu di Papua maupun luar Papua.

\section{Faktor Disposisi/Sikap Pelaksana}

Menurut George C Edwards dalam Leo Agustino (2006, p.152), disposisi atau sikap dari kebijakan adalah elemen penting ketiga dalam pendekatan mengenai pelaksanaan suatu kebijakan publik. Jika pelaksanaan suatu kebijakan ingin efektif, maka para pelaksana kebijakan tidak hanya harus mengetahui apa yang akan dilakukan tetapi juga harus memiliki kemampuan untuk melaksanakannya, sehingga dalam praktiknya tidak terjadi bias. Hal-hal penting yang perlu dicermati pada variabel disposisi, menurut George C. Edwards III dalam Agustino, (2016, p. 152), adalah Pengangkatan Birokrat dan Insentif.

\section{Pengangkatan Birokrat di BKPSDM}

Berdasarkan hasil wawancara dengan Kepala BKPSDM Kabupaten Yalimo dan Sekretaris BKPSDM Kabupaten Yalimo dapat dikatakan bahwa dalam pengangkatan Pegawai Negeri sudah ada prosedur tersendiri. Daerah atau Organisasi Perangkat Daerah tidak bisa melakukan penerimaan pegawai, karena ini berhubungan dengan masalah penggajian pegawai yang akan diterima atau diangkat tersebut yang merupakan kewenangan pemerintah pusat. Namun yang menjadi permasalahan selanjutnya, penempatan pegawai dari hasil penerimaan tersebut terkadang tidak sesuai dengan kebutuhan SKPD/OPD karena ada kepentingankepentingan tertentu. Sementara untuk pengangkatan pejabat struktural di BKPSDM sudah ada aturannya sendiri dan merupakan kewenangan penuh Kepala Daerah selaku pejabat pembina kepegawaian

\section{Insentif di BKPSDM}

Berdasarkan hasil wawancara dengan Bapak Martias Kepno selaku Kasubbag Umum dan Keuangan BKPSDM Kabupaten Yalimo, Ibu Basno selaku Kasubbid Penjenjangan Diklat Struktural dan Teknis Fungsional BKPSDM dan Bapak Syamsudin selaku Kasubbid Anggaran pada Badan Keuangan Daerah Kabupaten Yalimo, dapat disimpulkan bahwa insentif yang berlaku di BKPSDM itu ternyata memang berlaku umum secara keseluruhan bagi setiap pegawai di BKPSDM karena memang berdasarkan Peraturan Bupati tersebut, insentif itu berlaku bagi semua pegawai di lingkungan BKPSDM tidak berdasarkan absensi, kinerja, ataupun tingkat kemampuan menyelesaikan sebuah pekerjaan. Jadi dapat dikatakan bahwa insentif yang ada tidak menambah atau meningkatkan kinerja keinginan dan kemauan pelaksana dalam melakukan perintah dengan baik, karena rajin ataupun tidak rajin, mampu ataupun tidak mampu melaksanakan sebuah pekerjaan, tetap saja mendapatkan insentif/tunjangan beban kerja yang sama. 


\section{Faktor Struktur Birokrasi \\ Faktor Struktur Birokrasi}

Hasil wawancara peneliti dengan

Kasubbag Penyusunan Program

BKPSDM pada hari Rabu tanggal 7 April

2021 pukul 11.20 WIT diperoleh informasi

bahwa struktur organisasi yang ada saat ini memang sesuai dengan Perbup Nomor 16 tahun 2016, dan semua struktur telah terisi, akan tetapi untuk UPT memang belum ada SDM yang mengisinya.

Berdasarkan fakta yang ada dilapangan dapat dikatakan bahwa struktur organisasi yang saat ini berjalan di BKPSDM Kabupaten Yalimo sesuai dengan struktur yang ditetapkan oleh Peraturan Bupati Nomor 16 tahun 2016. Sementara untuk UPT masih terbentur dengan SDM dan fasilitas yang belum tersedia. Dengan struktur yang ada saat ini, kinerja BKPSDM memang bisa berjalan cukup baik, hanya yang kurang adalah pada saat koordinasi internal BKPSDM yang di koordinir oleh sekretaris BKPSDM terkadang sedikit menemui kendala. Kepala-kepala bidang merasa mempunyai eselon yang sama dengan sekretaris, selain itu ego antar bidang tampak terjadi, karena merasa mempunyai beban dan tanggung jawab yang sama. Dengan demikian struktur birokrasi sudah sesuai dengan peraturan Bupati Yalimo.

\section{Faktor Standar Operasional Prosedur (SOP)}

Berdasarkan hasil wawancara dengan Bapak Yohanes Lani selaku Kasubbag Penyusunan Program BKPSDM, Kabid Pengembangan SDM BKPSDM Kabupaten Yalimo, dan Kabid Pemanfaatan Teknologi Tepat Guna (TTG) Dinas Pemberdayaan Masyarakat Kampung Kabupaten Yalimo dapat dikatakan bahwa di BKPSDM belum ada standar operasional prosedur atau standar pelayanan minimal tentang pelaksanaan tugas pokok dan fungsi dari BKPSDM itu sendiri, dan bahkan hampir di semua SKPD belum rnernpunyai standar operasional prosedur, kecuali institusi yang berhubungan dengan pelayanan langsung kepada masyarakat seperti rumah sakit, ataupun pelayanan perizinan.

\section{Faktor Penghambat}

Faktor-faktor penghambat ini dapat berbeda dari setiap impementasi kebijakan yang ada. Dalam implementasi kebijakan pengembangan kompetensi sumber daya Aparatur sipil Negara di Kabupaten Yalimo, peneliti akan melihat faktor- faktor yang menghambat implementasi kebijakan pengembangan sumber daya ASN di Kabupaten Yalimo dari faktor anggaran, faktor fasilitas, dan faktor politik.

\section{Faktor Keterbatasan Anggaran}

Faktor penghambat dalam implemetasi kebijakan kompetensi sumber daya Aparatur Sipil Negara di Kabupaten Yalimo adalah anggaran yang masih belum memadai. Hal ini didukung oleh Kasubbag Penyusunan Program BKPSDM Kabupaten Yalimo, hari, Jumat 9 April 2021, pukul 9.00 WIT yang mengatakan bahwa program dan kegiatan Diklat PIM, selalu dilakukan perencanaan dalam bentuk RKA dan disampaikan kepada TAPD berdasarkan data pejabat struktural yang belum mengikuti Diklat PIM. Tetapi kenyataannya, dana yang dianggarkan oleh Tim Anggaran Pemerintah Daerah (TAPD) belum mencukupi dengan alasan keterbatasan dana. Selain itu, lobi kepada pihak-pihak terkait juga sangat kurang sehingga disesuaikan dengan anggaran yang tersedia di DPA.

Berdasarkan hasil wawancara dengan para informan dan hasil observasi peneliti dapat disimpulkan bahwa faktor keterbatasan anggaran, kurangnya koordinasi dan komunikasi terhadap TAPD dan pihak terkait, serta kuota yang diberikan oleh Lembaga penyelenggara menjadi faktor penghambat dalam pengembangan kompetensi ASN melalui diklat.

\section{Faktor Keterbatasan Fasilitas}

Berdasarkan hasil wawancara dengan para informan, ketersediaan sarana dan prasarana penunjang penyelenggaraan Diklat PIM di Yalimo belum memadai, seperti gedung diklat, kendaraan, meja, kursi, papan tulis, white board dan peralatan lainnya. Hambatan lain juga terjadi pada ketersediaan sarana yang berbasis IT yang mempermudah koneksi ke distrik-distrik 
yang belum ada jaringan. Hal ini yang belum menjadi perhatian Pemerintah Yalimo sebagai upaya adaptasi di era industri 4.0 maupun era 5.0.

\section{Faktor Politik}

Berdasarkan hasil wawancara dengan para informan, dapat disimpulkan bahwa faktor politik menjadi salah satu faktor penghambat dalam pengangkatan pejabat struktural maupun penentuan peserta Diklat PIM. Hal ini dapat dilihat dari penempatan/pengangkatan pejabat struktural di mana kebijakan Kepala Daerah dan kepentingan politik sangat mempengaruhi. Proses rekrutmen PNS dalam jabatan struktural tidak dilakukan melalui mekanisme pengisian jabatan eselon eselon III dan eselon IV yang kosong dan tidak melalui usulan beberapa nama dari masing-masing Kepala SKPD kepada Baperjakat, kemudian Baperjakat mengadakan rapat untuk menentukan siapa yang akan mengisi posisi tersebut, tetapi kenyataan yang terjadi di Yalimo keputusan berada di tangan Bupati untuk memilihnya.

PNS yang berpolitik dan berpihak kepada Bupati terpilih memperoleh jasa dalam bentuk timbal balik jabatan, bahkan ada yang meloncat langsung dari eselon $\mathrm{IV} / \mathrm{a}$ ke III/a tanpa melalui naik dulu ke eselon III/b baru kemudian ke III/a. Dengan demikian, hubungan pejabat politik dengan pejabat struktural birokrasi pada pemerintahan di daerah telah menjadi bagian dari catatan buruk dalam penyelenggaraan pemerintahan daerah.

\section{Upaya Mengatasi Faktor Penghambat Faktor Keterbatasan Anggaran}

Berdasarkan hasil wawancara dengan para informan, dapat disimpulkan bahwa upaya yang telah dilakukan oleh pemerintah Kabupaten Yalimo dalam mengatasi faktor penghambat dari faktor anggaran adalah perbaikan proses perencanaan anggaran dengan cara penyusunan RKA SKPD dengan data-data yang akurat, misalnya konsultasi dengan pihak penyelenggara Badan Diklat Provinsi Papua terhadap biaya kontribusi peserta Diklat PIM dan pengajuan telaahan staf kepada Bupati Yalimo. Telaahan diajukan kepada Kepala Daerah selaku Pemegang Kekuasaan Pengelolaan Keuangan Daerah.

Hal ini juga dikoordinasikan dengan pihak-pihak terkait, seperti BAPPEDA, Badan Keuangan Daerah (BKD), dan TAPD yang diketuai oleh Sekretarus Daerah. Selain itu BKPSDM Kabupaten Yalimo melakukan peningkatan intensitas komunikasi dan koordinasi dengan pihakpihak yang berkepentingan.

\section{Faktor Keterbatasan Fasilitas}

Berdasarkan hasil wawancara dengan para informan, dan hasil observasi yang dilakukan peneliti, diperoleh data bahwa perencanaan pengembangan kompetensi ASN selalu diprogramkan termasuk peningkatan sarana dan prasarana Diklat, namun pelaksanaan Diklat PIM tiap tahun selalu ada, walaupun jumlahnya terbatas. Pelaksanaan diklat PIM dilakukan di luar Kabupaten Yalimo, hal ini disebabkan karena fasilitas Diklat PIM belum memadai sehingga terdapat upaya lain juga yang dilakukan melalui pengembangan kompetensi melalui Pendidikan formal.

\section{Faktor Politik}

Berdasarkan hasil wawancara dengan para informan, dapat disimpulkan bahwa terdapat upaya yang dilakukan oleh BKPSDM Yalimo yaitu memberikan kesempatan kepada pejabat yang telah dilantik baik itu Eselon II, Eselon III dan Eselon IV untuk mengikuti Diklat PIM yang diselenggarakan oleh Badan Diklat Provinsi Papua maupun Kabupaten Jayawijaya atau penyelenggara lainnya di luar Papua yang disesuaikan dengan kemampuan keuangan daerah dan kuota yang didapat dalam rangka peningkatan/pengembangan kompetensi. Selain itu terdapat upaya lain yang dilakukan oleh BKPSDM yaitu telah menyampaikan telaahan staf kepada kepala daerah terkait pengangkatan pejabat struktural di BKPSDM dan semua SKPD/OPD. Terdapat juga upaya lain yaitu dilakukanya penyusunan SOP agar proses seleksi lebih transparan. Sedangkan upaya yang dilakukan SKPD adalah dengan pelatihan, atau kursus, seminar yang pendanaannya dianggarkan melalui DPA SKPD masing-masing. 
Peneliti berpendapat bahwa persoalan politisasi birokrasi hendaknya dapat diminimalisir sehingga nantinya birokrasi betul-betul bersih dari kepentingan politik. Oleh karena itu, segala aturan yang mengatur tentang netralitas PNS juga harus dijalankan.

\section{KESIMPULAN DAN SARAN}

\section{Kesimpulan}

Berdasarkan analisa data hasil penelitian terkait dengan implementasi kebijakan pengembangan kompetensi sumber daya ASN melalui Pendidikan dan Pelatihan Kepemimpinan (Diklat PIM) di Kabupaten Yalimo, diperoleh kesimpulan sebagai berikut :

1. Implementasi kebijakan pengembangan kompetensi sumber daya ASN di Kabupaten Yalimo Provinsi Papua dalam meningkatkan kompetensi ASN belum berjalan optimal. Hal ini tampak dari 4 (empat) dimensi dalam penelitian ini yaitu :
a. Dimensi Komunikasi, belum berjalan dengan baik.
b. Dimensi Sumber Daya, belum berjalan dengan optimal.
c. Dimensi Disposisi, belum berjalan dengan optimal.
d. Dimensi Struktur Birokrasi, belum berjalan dengan baik.

2. Terdapat faktor penghambat implementasi kebijakan pengembangan kompetensi sumber daya ASN di Kabupaten Yalimo yaitu :
a. Faktor Keterbatasan anggaran.
b. Faktor keterbatasan Fasilitas.
c. Faktor Politik.

3. Terdapat upaya mengatasi faktor penghambat yang dilakukan oleh pemerintah Kabupaten Yalimo melalui BKPSDM Yalimo. Upaya yang dilakukan untuk mengatasi faktor penghambat sebagai berikut :
a. Faktor Keterbatasan Anggaran. Upaya yang dilakukan adalah perbaikan proses perencanaan anggaran dengan cara penyusunan RKA SKPD dengan data-data yang akurat.
b. Faktor Keterbatasan Fasilitas. Dari faktor ini upaya yang dilakukan adalah melakukan perencanaan

\begin{abstract}
pengadaan sarana dan prasaran/fasilitas, membangun komunikasi dan koordinasi yang intensif ke pihak penyelenggara, seperti Badan Diklat Provinsi Papua dan Pemerintah Kabupaten Jayawijaya serta Lembaga penyelenggara Diklat PIM lainnya di luar Provinsi.

c. Faktor Politik. Upaya yang dilakukan untuk mengatasi faktor penghambat adalah menyusun Standar Operasional Prosedur (SOP) agar ada transparansi dalam penetapan peserta. Selain itu, BKPSDM telah menyampaikan telaahan staf kepada kepala daerah terkait proses seleksi peserta Diklat PIM dan pengangkatan pejabat struktural di lingkungan pemerintah Kabupaten Yalimo. Upaya lain yang dilakukan SKPD adalah dengan pelatihan, atau kursus, seminar yang pendanaannya dianggarkan melalui DPA SKPD masing-masing.
\end{abstract}

\section{Saran}

Berdasarkan kesimpulan hasil penelitian di atas, maka peneliti memberikan saran sebagai berikut:

1. Badan Kepegawaian dan Pengembangan Sumber Daya Manusia (BKPSDM) Kabupaten Yalimo perlu mengimplementasikan pengembangan kompetensi sumber daya ASN dengan cara:

a. Meningkatkan komunikasi dengan cara inovasi-inovasi baru, dengan menggunakan teknologi informasi.

b. Meningkatkan sumber daya dengan cara pengelolaan SDM yang baik yaitu dengan melakukan perencanaan pengembangan kompetensi ASN/PNS dan pembinaan SDM serta fasilitas lainnya yang memadai

c. Menata disposisi dengan cara cara menerapkan manajemen sumber daya aparatur yang sepatutnya berdasarkan aturan yang berlaku dengan memperhatikan kompetensi dan potensi aparatur dalam proses rekruitmen serta pemberian jabatan. 
d. Menata pola kerja struktur Birokasi dengan cara menyusun/membuat standar operasional prosedur di BKPSDM Kabupaten Yalimo, sehingga kinerja pelayanan publik yang dilakukan oleh BKPSDM dapat terukur dan tersistematis dengan baik.

2. Badan Kepegawaian dan Pengembangan Sumber Daya Manusia (BKPSDM) Kabupaten Yalimo perlu melakukan perbaikan terhadap faktor penghambat yang ada yaitu:

a. Perlu melakukan penambahan anggaran dengan cara melakukan perencanaan program dan anggaran sesuai kebutuhan.

b. Perlu menambah fasilitas antara lain fasilitas kantor berupa Gedung pelatihan, meja dan kursi.

c. Perlu penataan proses seleksi peserta Diklat PIM yang transparan dan pengangkatan birokrat dalam pejabat struktural yang sesuai dengan kompetensi ASN.

3. Peneliti selanjutnya diharapkan untuk mengkaji lebih banyak sumber maupun referensi yang terkait dengan implementasi kebijakan pengembangan kompetensi sumber daya aparatur sipil agar hasil penelitian dapat lebih baik dan lebih lengkap lagi.

\section{DAFTAR PUSTAKA}

Abidin, Z. S. (2012). Kebijakan Publik. Jakarta: Salemba Humanika.

Agustino, L. (2008). Dasar-dasar Kebijakan Publik. Bandung: Alfabeta.

--------. (2017). Dasar-dasar Kebijakan Publik. Bandung : Alfabeta.

Alwi, S. w. (2014). Manajemen Sumber Daya Manusia dalam Organisasi Publik. Jatinangor Sumedang Jawa Barat: IPDN Press.

Creswell, J. W. (2007). QUALITATIVE INQUIRY AND RESEARCH DESIGN Choosing Among Five Approaches. The United States of America: Sage Publication Inc.

(2013). Research Design Pendekatan Kualitatif, Kuantitatif dan Mixed. Yogyakarta: Pustaka Pelajar.

Devito, J. (2002). Komunikasi Antar Manusia. Jakarta: Profesional Books.

Dunn, W. N. (2003). Pengantar Analisis Kebijakan Publik Edisi Kedua. Yogyakarta : Gadjah Mada University Press.

Edwards, G. III (1980). Impelementing Public Policy. Washington City: Congressional Quarterly Press.

Erwan Purwanto Agus, D. R. (2015). Implementasi Kebijakan Publik Konsep dan Aplikasinya di Indonesia. Yogyakarta: Gava Media.

Gering, S. (2012). Proccending Seminar prospek Penerapan Desentralisasi Asimetris dalam Sistem Pemerintahan Daerah di Indonesia . Bandung: Lembaga Administrasi Negara.

J.A, D. (2002). Komunikasi Antar Manusia. Jakarta: Profesional Books.

Kartawidjaja, D. H. (2011). Konsep dana Efektivitas Implementasi Kebijakan Keselamatan dan Kesehatan Kerja (K3). Jakarta: Madani Publishing.

Keputusan Kepala LAN nomor: 18,19 dan 20 Tahun 2015

Kumar, R. (2011). Reseaarch Methodology a step-by-step guide for beginners. Los Angeles: SAGE Publication Inc.

Labodo, M. (2015). Dinamika POlitik dan Pemerintahan Lokal . Ciawi-Bogor: Ghalia Indonesia.

Luankali, B. (2007). Analisis Kebijakan Publik dalam Proses Pengambilan Keputusan . Jakarta: Percetakan AMELIA.

Maleong Lexy J. (2012) Metodologi Penelitian.Bandung: PT.Remaja Rosdakarya

Matthew B. Miles, A. M. (2014). Qualitative data analysis: a methods sourcebook. Arizona State University: SAGE Publications, Inc.

Mulyana, D. (2012). Ilmu Komunikasi Suatu Pengantar. Bandung: PT Remaja Rosdakarya.

Mustopadidjaya, A. (2002). Manajemen proses kebijakan publik. Formulasi, implementasi, dan evaluasi kinerja. Jakarta: Lembaga Administrasi Negara-RI. 
Muttalib dan Moch.Akbar, A. (2013). Teori Of Local Goverment (Teori Pemerintahan Daerah). Jakarta: MIPI.

Ndraha, T. (2002). Kybernologi(Ilmu Pemerintahan Baru). Jakarta: PT.Rineka Cipta.

Noor Juliansah. (2012). Metodologi Penelitian. Jakarta: Kencana Prenada Media Group.

Peraturan Pemerintah Nomor 11 Tahun 2017 tentang Manajemen Aparatur Sipil Negara.

Peraturan Pemerintah Nomor 18 Tahun 2016 tentang Perangkat Daerah

Peraturan Daerah Nomor 5 Tahun 2014 tentang Organisasi dan Tata Kerja Badan Kepegawaian,Pendidikan dan Pelatihan Aparatur (BKPPLA) Kabupaten Yalimo

Peraturan Bupati Yalimo Nomor 16 Tahun 2016 tentang Kedudukan, Susunan Organisasi, Tugas dan Fungsi serta Tata Kerja Badan Kepegawaian dan Pengembangan Sumber Daya Manusia.

Purwanto, E. A. (2012). Implementasi Kebijakan Publik. Yogyakarta: Gava Media.

Riyadi, e. (2010). Kajian Penyusunan Instrumen Pengukuran Good Administration bagi Pemerintah Daerah Pusat Kajian dan Pendidikan dan Pelatihan Aparatur I. Jatinangor Jawa Barat.

Sedarmayanti. (2017). Manajemen Sumber Daya Manusia Reformasi Birokrasi dan Manajeen Pegawai Negeri Sipil. Bandung: PT.Refika Aditama.

Subarsono. (2011). Analisis Kebijakan,Konsep,Teori dan Aplikasi . Yogyakarta: Pustaka Pelajar.(n.d.).

Sugyono. (2014). Metode Penelitian Kualitati Kuantitatif dan R d D. Bandung : Alfabeta.

Supryadi, Gering 2012, Wacana Kinerja, Kajian Praktik-Akademisi Kinerja Kebijakan dan Administrasi
Pelayanan Publik, Pusat Kajian dan Pendidikan Latihan I, Lembaga Administrasi Negara ( LAN ). Jatinangor Jawa Barat.

Suradinata, E. (2016). Analisis Kepemimpinan Strategy Pengambilan Keputusan (ASOCA). Jatinangor: AI Qaprint.

Setyowati , Retno dan Muhammad Mathori, Riset Manajemen ( Analisis

Kualitas Sumber Daya Manusia di Badan Pengawasan Keuangan dan Pembangunan (BPKP)

Ulber dan Wirman Syafri, S. (2015).

Desentralisasi dan Demokrasi Pelayanan Publik. Jatinangor Sumedang Jawabarat: IPDN Press.

Undang-undang Nomor 4 Tahun 2008 tentang Pembentukan Kabupaten Yalimo

Undang-undang nomor 5 Tahun 2014 Tentang Aparatur Sipil Negara.

Venote. (2010, November 16 Februari 2020). Teori Implementasi Edwards III. Teori Implementasi Edwards III. Jakarta.

Wahab, S. A. (1997). Analisis Kebijaksanaan Negara. Jakarta: Rineka Cipta.

(2008). Pengantar Analisis Kebijakan Publik. Malang: Universitas Muhammadyah Press.

Widodo, j. (2007). Analisis Kebijakan Publik. Malang: Bayumedia.

Winarno, B. (2008). Kebijakan PublikTeori dan Proses. Jakarat: Buku Kita dan proses). Jakarta: Meddia
Pressindo.

Wirman Syafri, dan Israwan Setyoko. (2010). Implementasi Kebijakan Publik dan Etika Profesi Pamong Praja. Bandung: Alqaprint Jatinangor.

Yin, R. K. (2018). Case Study Research: Design and Methods. Los Angeles: Sage Publication Inc. 